\title{
Dieta roślinna i zaangażowanie społeczne w praktykach dyskursywnych społeczności internetowych
}

\author{
Plant-Based Diet and Social Involvement \\ in the Discursive Practices of Online Communities
}

\section{Wprowadzenie}

Preferencje żywieniowe i praktyki związane z jedzeniem, jakie w ostatnich latach obserwować można w społeczeństwie polskim, nie są już tylko nawiązaniem do rodzimej tradycji kulinarnej, ale mogą być postrzegane także jako znaczący marker wzrostu społecznego zróżnicowania i świadectwo zachodzących wokół zmian kulturowych. Wybór sposobu odżywiania staje się obecnie coraz częściej przedmiotem wielowymiarowych decyzji powiązanych ze świadomym angażowaniem się ludzi w rozmaite, ważne dla nich, problemy społeczne wynikające z aktualnej sytuacji gospodarczo-politycznej w kraju i na świecie oraz postępujących globalnych zmian klimatu. Wzorce żywieniowe wybierane z rozwagą przez wielu Polaków przekładają się zatem już nie tylko na codzienne czynności kulinarne, ale niejednokrotnie wiążą się z przyjmowanym przez nich sposobem postrzegania świata i stanowią podstawę do wyrażania poglądów dotyczących wielu ważnych kwestii z życia społecznego. Te spostrzeżenia wyraźnie korespondują ze słowami Pat Caplan, badaczki kultury kulinarnej, która podkreśla, że: „żywność nigdy nie jest «tylko jedzeniem» i jej znaczenie nigdy nie może być czysto odżywcze" ". Jedną z popularnych obecnie praktyk żywieniowych, coraz częściej świadomie podejmowanych także w Polsce, jest dieta roślinna, wykluczająca spożywanie mięsa, kojarzona głównie

I P. Caplan, Approaches to the Study of Food, Health and Identity, [w:] Food, Health and Identity, red. P. Caplan, London-New York 2003, s. 3. 
z wegetarianizmem lub weganizmem, a jej wybór wydaje się pozostawać w silnych korelacjach $\mathrm{z}$ aktualnymi przemianami kultury i środowiska. Jak podkreśla Anna Willetts: „Wegetarianizm oznacza nie tylko zmianę diety związaną z dbałością o zdrowie, ale także jest sposobem na wyrażanie światopoglądu tych, którzy go stosują"2. Doskonałą ilustracją specyfiki diety opartej na bazie produktów roślinnych oraz potwierdzeniem zależności, jakie zachodzą obecnie pomiędzy wyborem tej formy odżywiania w polskich warunkach a przyjmowaniem postaw zaangażowania w sprawy społeczne, stanowi, w moim przekonaniu, wzajemna komunikacja zwolenników roślinnego sposobu żywienia podejmowana w przestrzeni polskojęzycznych internetowych serwisów społecznościowych. Grupowe dyskusje prowadzone na portalach społecznościowych, zdaniem badaczy, pełnią obecnie funkcję podstawowego forum wymiany poglądów i doświadczeń dotyczących bardzo wielu ważnych kwestii z obszaru życia prywatnego ich uczestników - zdrowia i choroby, sposobów zamieszkiwania i spędzania czasu wolnego, podróżowania, wychowywania i edukacji dzieci, życia uczuciowego, opieki nad domowymi zwierzętami, a także gotowania i sposobów żywienia ${ }^{3}$. Przyjąć można, że rozmaite formy komunikacji podejmowanej na portalach społecznościowych funkcjonują jako jeden z najbardziej wrażliwych barometrów aktualnych nastrojów społecznych i stanowią odzwierciedlenie sposobów bycia w świecie ich użytkowników - ukazują specyfikę ich światopoglądu, preferowane przez nich style życia, najważniejsze pasje i zainteresowania, ale także lęki i wyzwania, przed jakimi stają oni w swoich codziennych działaniach. Użytkowanie internetu to dzisiaj bardziej modus vivendi niż tylko sposób porozumiewania się z innymi ${ }^{4}$. Taka sytuacja przynosi nowe wyzwania dla badaczy życia społecznego, którzy nie mogą pozostać obojętni wobec aktualnych zmian kulturowych i muszą sięgać do wszystkich tych przestrzeni, w których toczy się ludzkie życies.

Jak wygląda potoczne, nieformalne i jednocześnie światopoglądowo zaangażowane mówienie o jedzeniu? Jak postrzegana i oceniana jest w tym kontekście dieta roślinna? Jakie kwestie stają się najważniejsze w dyskusji podejmowanej przez zwolenników roślinnego jedzenia? W jakim związku

2 A. Willetts, „Bacon Sandwiches Got the Better of Me”. Meat-eating and Vegetarianism in South-East London, [w:] Food, Health..., s. in.

3 Por. K. Jurek, Badania spoteczne w internecie. Wirtualna etnografia w teorii i praktyce, „Nauka i Szkolnictwo Wyższe” 2013, nr I (4I), s. 90.

4 Por. J. Jakubasek, „Usta petne za jednym pociagnięciem” - internetowa kultura oralna, [w:] Antropologia praktyk kulinarnych. Szkice. Pongo, t. 5, red. R. Chymkowski, Warszawa 2012, s. I24.

5 Por. Ch. Hine, Virtual ethnography, Thousand Oaks 2000; M. Hammersley, P. Atkinson, Metody badań terenowych, przeł. S. Dymczyk, Poznań 2000, s. 163-165. 
pozostaje tego rodzaju dyskurs z problemami współczesnego świata? Jak nawiązuje do polskiej tradycji kulturowej? Do podjęcia próby odpowiedzi na tak postawione pytania skłoniła mnie, prowadzona od dłuższego czasu, intensywna obserwacja wzajemnej komunikacji zwolenników diety roślinnej (wegetarian i wegan) skupionych w różnych grupach tematycznych na jednym z portali społecznościowych. Uczestnictwo w takich tematycznie sprofilowanych grupach internetowych podyktowane zostało moimi osobistymi potrzebami i pozwoliło mi nie tylko poznawać nowe przepisy kulinarne i czerpać rozmaite inspiracje dotyczące bliskiej mi formy odżywiania, ale także stopniowo oswajało z określonym sposobem postrzegania rzeczywistości i specyfiką komentowania zachodzących w niej zdarzeń. W efekcie na podstawie obserwowanej przeze mnie internetowej komunikacji i stosowanych w niej form dyskursu oswoiłam się z określonym typem światopoglądu, który zakłada stosowanie diety roślinnej, ale ujawnia także silne zaangażowanie $\mathrm{w}$ wiele powiązanych z problematyką jedzenia kwestii, ważnych w aktualnym życiu społecznym zarówno w skali lokalnej, jak i w perspektywie globalnych wyzwań, jakie stają dziś przed producentami i konsumentami żywności. Podejście zaangażowane więc w tych rozważaniach występuje niejako podwójnie - jako postawa członków wybranych do opisu grup internetowych oraz jako moje autorskie wsparcie dla ich poglądów i doświadczeń.

\section{Metodologia}

W podejmowanych badaniach interesował mnie przede wszystkim sposób wzajemnej wymiany myśli w środowisku zwolenników diety roślinnej, którzy tworzą grupy tematyczne na jednym z bardziej popularnych obecnie portali społecznościowych, jakim jest Facebook (wersja polskojęzyczna). Moje poczynania badawcze mieściły się w ramach etnograficznego badania społeczności internetowych, utworzonych i funkcjonujących w takiej formie wyłącznie w przestrzeni wirtualnej $j^{6}$, a przyjętą metodę badań stanowiła dla mnie etnografia wirtualna ${ }^{7}$, nazywana przez antropologów również etnografią internetową ${ }^{8}$, e-etnografią czy netnografią', w połączeniu

6 Por. rozróżnienie pomiędzy badaniem „społeczności internetowych” a badaniem „społeczności w internecie” (zob. uwagi na ten temat w pracy Roberta Kozinets'a, Netnografia. Badania etnograficzne online, przeł. M. Brzozowska-Brywczyńska, Warszawa 2012, s. 98-100).

7 Ch. Hine, dz. cyt., passim.

8 L. Sade-Beck, Internet Ethnography. Online and Offline, „International Journal of Qualitative Methods" $2008, \operatorname{nr}_{3}$ (2), s. 45-5I.

9 R.V. Kozinets, dz. cyt., s. 98-ıо०. 
z analizą dyskursu. Etnografia wirtualna, zdaniem specjalistów, zakłada wykorzystanie całego zestawu praktyk badawczych związanych z gromadzeniem $i$ analizą danych, zebranych w środowisku wirtualnym w oparciu głównie o obserwację zachowań komunikacyjnych użytkowników sieciro ${ }^{\circ}$. Zastosowanie etnografii wirtualnej w badaniu praktyk jedzeniowych wyrażać ma jednocześnie moje badawcze uznanie dla eksploracji komunikacji zapośredniczonej przez sieć i jej wagi we współczesnym życiu społecznym. Wspomnieć tu można oczywiście o pewnych ograniczeniach badań netnograficznych, wynikających z trudności w określeniu dokładnej próby badawczej czy z braku możliwości dotarcia do „autentycznych” ludzkich aktywności, ale jednocześnie trzeba podkreślić, że przestrzeń serwisów społecznościowych pozwala docierać do takich sposobów wymiany myśli, które współcześnie coraz rzadziej mają miejsce w innych przestrzeniach komunikacyjnych.

Badane przeze mnie społeczności internetowe to przede wszystkim środowiska tekstowe, w których wszystkie interakcje oparte były głównie na wymianie wiadomości pisanych i uzupełniających te przekazy treści wizualnych. Prowadzone intensywne obserwacje nie dotyczyły zatem faktycznych zachowań ludzi, a jedynie konstruowanych przez nich wypowiedzi na potrzeby uczestnictwa w wybranej społeczności. Wypowiedzi te lokować należy gdzieś na pograniczu źródeł formalnych i nieformalnych. Z jednej strony, dotyczą one z pewnością codziennych, prywatnych doświadczeń z życia konkretnych ludzi, z drugiej zaś, udostępniane są publicznie dla szerokiego grona nieznanych bliżej członków internetowej grupy. Jak zauważa jednak Dariusz Jemielniak, granica pomiędzy sferą publiczną i prywatną w komunikacji online jest właściwie rozmyta: „wiele dialogów prowadzi się w półprywatny sposób, z założeniem, że choć są dostępne publicznie (lub dostępne wyłącznie dla członków społeczności), w praktyce dostęp do nich ze strony ogółu społeczności nie istnieje" ${ }^{\prime \prime}$. W efekcie rozmowy prowadzone są w ograniczonym kręgu osób zainteresowanych. Piśmienność stanowi dla członków badanych społeczności jedyny możliwy sposób na eksponowanie ich grupowej i jednostkowej tożsamości. I choć ta tożsamość może podlegać pewnej kreacji i różnić się od tożsamości okazywanej w życiu realnym ${ }^{12}$, to mamy zapewne do czynienia $\mathrm{z}$ nawiązywaniem społecznych relacji, zbliżonych do tych, które znamy $\mathrm{z}$ innych sytuacji

\footnotetext{
Io Por. tamże, s. 294-295.

II D. Jemielniak, Życie wirtualne dzikich. Netnografia Wikipedii, największego projektu wspóttworzonego przez ludzi, Warszawa 2013, s. 283.

I2 Tamże, s. 282.
} 
życiowych. Użytkownicy komunikacji internetowej, jak w każdej formie wymiany myśli zapośredniczonej przez pismo, występują w rolach społecznych wyznaczonych przez specyfikę podejmowanych interakcji online, a ich tożsamość wyraża się w przyjmowanych przez nich w tych okolicznościach sposobach mówienia ${ }^{13}$. Warto dodać, że tworzenie i podtrzymywanie fałszywych tożsamości okazuje się niezwykle trudne w dłuższym wymiarze czasowym, a odkrywanie własnej prywatności na portalach społecznościowych staje się coraz częściej nie tylko rodzajem przyjemnej rozrywki, ale także ważnym elementem budowania własnego stylu życia. Wszystko to pozwala etnografowi odnajdywać w internetowych dyskusjach informacje równie cenne, jak te zbierane w badaniach „twarzą w twarz” i pozyskiwać dane dotyczące określonego typu kultury. Jak zaobserwowała Christine Hine: „Zasadne z punktu widzenia etnografii są wszelkie formy interakcji, nie tylko te zachodzące «twarzą w twarz». Kształtowanie obiektu badań etnograficznych w formie, w której umożliwiają to środki techniczne, to też etnografia. Jest to etnografia w świecie wirtualnym, dotycząca świata wirtualnego i przezeń badana" ${ }^{4}$.

Opisywane przeze mnie badanie kultury społeczności internetowej było więc przede wszystkim etnograficznym badaniem piśmienności, sposobów używania słów i docieraniem do kryjących się za nimi ładunków znaczeniowych. W prowadzonych analizach założyłam, że to dyskurs buduje znaczenie słów i wyrażeń, a w tym procesie biorą udział doświadczenia kulinarne uczestników komunikacji oraz reprezentowany przez nich światopogląd. Przyjęte przeze mnie rozumienie analizy dyskursu oznaczało badanie sposobów użycia języka w określonym oryginalnym kontekście sytuacyjnym, ale także społecznym, politycznym i gospodarczym ${ }^{15}$. Prowadzone analizy polegały na badaniu internetowej komunikacji językowej skupionej wokół tematu roślinnego jedzenia, dlatego też przedmiotem moich zainteresowań stały się przede wszystkim szczegółowe tematy wypowiedzi, styl, forma i słowa klucze (kod kulinarny), ale także cała sytuacja komunikacyjna, zakładająca wzajemną wymianę zdań użytkowników tematycznych grup społecznościowych w określonej czasoprzestrzeni. Jak podkreślają bowiem badacze jedzenia: ,jedzenie jest jak język - jego znaczenie może zmieniać się w zależności od kontekstu czasu i miejsca, a ludzie mogą zmieniać kody

I3 Por. A.P. Wejland, Zatożenia teoretyczne i metodologiczne badań Internetu $i$ w Internecie. Kilka uwag krytycznych, [w:] Homo interneticus: etnograficzne wędrówki w gtąb sieci, red. E. Jagiełło, P. Schmidt, Lublin 20 Io, s. Io.

I4 Ch. Hine, dz. cyt., s. 65.

Is Por. T.A. van Dijk, Badania nad dyskursem, [w:] Dyskurs jako struktura i proces, red. T.A. van Dijk, przeł. G. Grochowski, Warszawa 2001, s. 28-32. 
jedzeniowe tak samo jak kody językowe, w zależności od tego, z kim się komunikują w danym momencie" ${ }^{\text {"6 }}$.

Po dokonaniu wstępnego rekonesansu badawczego udało mi się wybrać do szczegółowych badań kilka grup użytkowników Facebooka, w których nazwach eksponowany był nacisk na dietę roślinną, by w kolejnym kroku zaangażować się w skrupulatne zbieranie danych potrzebnych do przeprowadzenia właściwych analiz i interpretacji oraz postawienia wniosków końcowych ${ }^{17}$. Przedmiotem prowadzonych przez kilka miesięcy obserwacji były wypowiedzi zamieszczane w sześciu dyskusyjnych grupach tematycznych, z których do szczegółowej analizy ostatecznie wybrałam tylko dwie grupy prywatne, zrzeszające największą liczbę użytkowników i wykazujące największą codzienną aktywność w publikowaniu postów. Pierwsza z nich miała około pięcioletni staż i prawie 50 tys. użytkowników, druga zaś funkcjonowała od ponad dwóch lat i skupiała społeczność około is tys. członków, zarówno kobiet, jak i mężczyzn ${ }^{18}$. Prowadzone przeze mnie obserwacje trwały sześć miesięcy (od października 2019 r. do marca roku 2020). W procesie badawczym występowałam w roli aktywnego użytkownika obserwowanych grup ${ }^{19}$ i zdecydowanie opowiadałam się po stronie badanych społeczności, zgadzając się zasadniczo z prezentowanymi w grupach treściami. I choć tradycyjna antropologia przestrzegała przed angażowaniem się proces badań własnego środowiska kulturowego, to nie tylko ma ono pewne zalety, ale w przypadku badania społeczności internetowych może przynieść dodatkowe korzyści poznawcze ${ }^{20}$. W odniesieniu do badanych przeze mnie grup wewnętrzna znajomość tego środowiska umożliwiła z pewnością pełniejsze zrozumienie prowadzonej w nich komunikacji, w której każdy z użytkowników do pewnego stopnia czuł się zapewne „obcym” i reprezentował nieco inną, właściwą sobie kulturę lokalną. Dodatkowo w prowadzonym badaniu występowałam jako badacz niejawny, zakładając, że przyjęcie strategii pełnej otwartości badawczej może nie przynieść pożądanych rezultatów ${ }^{21}$. Ze względów etycznych zachowałam jednak pełną anonimowość w stosunku do nazw badanych grup, rezygnując także z dosłownego cytowania zebranych w badaniu wypowiedzi.

\footnotetext{
I6 P. Caplan, dz. cyt., s. 6.

17 Por. R.V. Kozinets, dz. cyt.

I8 W obserwowanych dyskusjach zauważyć można niewielką przewagę kobiet, ale intensywnie uczestniczą w nich również mężczyźni. Płeć nie stanowi czynnika wyraźnie determinującego wypowiedzi użytkowników, dlatego też nie będę szerzej rozwijać tej kwestii.

I9 Por. K. Jurek, dz. cyt., s. 90.

20 Por. D. Jemielniak, dz. cyt., s. 274.

2I Por. K. Jurek, dz. cyt., s. 91-92.
} 


\section{Grupowe dyskusje o jedzeniu}

Uczestnicy obserwowanych przeze mnie grupowych konwersacji określali siebie jako osoby stosujące lub próbujące wprowadzić w swojej praktyce kulinarnej dietę roślinną, którą należy rozumieć jednak umownie, jako sposób odżywiania bazujący głównie na produktach roślinnych (warzywach, ziarnach, orzechach, nasionach, roślinach strączkowych i owocach) oraz całkowicie wykluczający mięso. Tego rodzaju identyfikacja stanowiła podstawę zachodzącej w grupach komunikacji i wyznaczała ramy wszystkich podejmowanych dyskusji. Pośród użytkowników obserwowanych grup, biorących udział w rozmowach, spotkać można było zarówno wegetarian (początkujących i bardziej zaawansowanych), jak i wegan ${ }^{22}$, którzy wyraźnie podkreślali kwestię rezygnacji z wykorzystywania produktów pochodzenia zwierzęcego w każdym aspekcie swojego życia. Autorzy badanych wpisów rzadko praktykowali dietę roślinną od urodzenia czy wczesnego dzieciństwa - były to zwykle osoby dorosłe, które dokonały świadomej zmiany sposobu odżywiania dopiero w ciągu kilku ostatnich lat. Przyznawali oni otwarcie, że są na różnych etapach drogi zmierzającej do całkowitego przejścia na dietę roślinną, a ich motywacje wynikały $z$ wielu powodów, choć do najważniejszych z nich należały względy zdrowotne, związane z dbałością o kondycję własnego ciała, a w drugiej kolejności także kwestie ekologiczne i etyczne, które nabierały znaczenia w kontekście przekazów medialnych związanych z krytyką mięsnego jedzenia. W grupowych dyskusjach użytkownicy Facebooka wspominali początki swojego przejścia na dietę roślinną, które najczęściej stanowiły rodzaj „eksperymentu podejmowanego na własnym organizmie” ${ }^{23}$, który „wymagał wytrwałości”, ale zawsze przynosił tylko „korzystne rezultaty” oraz „lepsze samopoczucie fizyczne i psychiczne”. Wybór diety roślinnej określali oni jako „najważniejszą decyzję w życiu”, przekładającą się na „styl życia, a nie dietę", który z czasem zaczynał mieć silny związek ze zmianą ich światopoglądu i krytyczną oceną otaczającej rzeczywistości.

Podstawowym tematem grupowego dyskursu było oczywiście jedzenie roślinne. Zamieszczane w grupie posty i komentarze prezentowały głównie wiedzę dotyczącą sposobów wykorzystania w kuchni poszczególnych

22 W badanych przeze mnie społecznościach właściwie nie funkcjonował wyraźny podział na wegetarian i wegan, dlatego też używam tych pojęć w dość ograniczonym wymiarze. Wielu członków badanych społeczności mówiło raczej o swojej wieloetapowej drodze do ostatecznego stosowania diety wyłącznie roślinnej.

23 Sformułowania ujęte w tekście w cudzysłów nie stanowią cytatu z pojedynczej wypowiedzi, a ilustrują najbardziej typowe określenia badanego dyskursu, często powtarzane w wypowiedziach członków badanych społeczności. Traktować je można zatem jako zwroty charakterystyczne dla kodu językowego, używanego na forum badanych grup. 
produktów roślinnych, a także służyły wzajemnej wymianie kulinarnych doświadczeń. Język przytaczanych w postach przepisów był bardzo podobny do ustalonego wzorca tego gatunku mowy ${ }^{24}$. W zamieszczanych wypowiedziach pojawiała się najpierw umowna nazwa prezentowanego dania, a w komentarzach, dodawanych na prośbę czytających, autor zamieszczał wykaz produktów, połączony z opisem sposobu wykonania potrawy. Ilość potrzebnych artykułów spożywczych podawana była często umownie, a kolejność ich dodawania/łączenia pozostawała kwestią intuicji gotującego - cenne stawało się kulinarne doświadczenie. Obserwując posty zamieszczane przez członków badanych grup, z łatwością wskazać można produkty spożywcze najczęściej wykorzystywane w ich praktykach kulinarnych, do których należały przede wszystkim warzywa - soczewica (zielona i czerwona), ciecierzyca, kapusta, buraki, cebula, czosnek, szpinak, pomidory (świeże i suszone), papryka, ziemniaki, rzepa, marchew, fasola, groch, brokul, cukinia, por, seler naciowy, bakłażan, kukurydza oraz grzyby (boczniaki i rzadziej pieczarki). W czasie prowadzonych obserwacji (okres jesienno-zimowy) w gronie najczęściej przywoływanych owoców znaleźć można było awokado, oliwki, banany, borówki, gruszki i jabłka, a pośród przypraw wymieniano sól, pieprz, świeże zioła (bazylię, kolendrę, pietruszkę, szczypiorek), wędzoną paprykę, curry, garammasalę, kurkumę, cynamon, nasiona konopi, ziarna komosy ryżowej (quinoa) lub słonecznika oraz różnego rodzaju orzechy, migdały, roślinne oleje, sos sojowy, ocet balsamiczny, śmietankę sojową i mleko kokosowe. Sporadycznie pojawiał się również nabiał - twarogi, ser mozzarella, camembert lub feta i jajka - oraz miód. Członkowie grup często dzielili się ze sobą przepisami na własnoręcznie wypiekany chleb lub bułki oraz różnego rodzaju słodycze (bezy, muffinki, ciasta marchewkowe, brownie z buraka czy jabłecznik). Ważnym motywem przewodnim wymiany informacji o kuchni roślinnej były też opinie o sposobach przygotowania i wykorzystania wybranych produktów, ważnych w diecie ze względu na swoje wartości odżywcze lub sezonową modę kulinarną (na przykład hummusu, tofu, awokado czy ciecierzycy). Krytyce poddawano zaś m.in. olej palmowy, którego produkcję określano jako „zbrodnię przeciwko ludzkości”, związaną z „rabunkowym pozyskiwaniem terenów" pod uprawy palmy olejowej, co stało się tragiczne w skutkach nie tylko dla środowiska naturalnego, ale i dla człowieka.

Użytkownicy obserwowanych dyskusji stosowali w swojej diecie wiele produktów znanych od dawna w polskiej tradycji kulinarnej, jedzonych na

24 Por. K. Orszulak-Dudkowska, Co kryją w sobieprzepisy kulinarne? Od folklorystyki do antropologii zmystów, „Literatura Ludowa” 2010, nr 4-5, s. 82-85. 
co dzień głównie w środowisku chłopskim, jak i podawanych w dorocznych okolicznościach obrzędowych (Wigilia, post), kojarzonych także z sytuacją powszechnego niedoboru żywności w polskich kuchniach z okresu PRL-u. Wykorzystywali więc własne kompetencje kulturowe i wcześniejszą wiedzę kulinarną, by na tej podstawie opisywać swoje aktualne poczynania z kuchnią roślinną. W zamieszczanych postach wspominali o znanych z tradycji rodzinnej i wciąż przygotowanych w swoich domach pierogach $\mathrm{z}$ kapustą i grzybami, czerwonym barszczu, zupie szczawiowej, kromkach chleba zapiekanych z jajkiem oraz domowych kiszonych ogórkach, kapuście lub burakach, zakwasie na żur lub zaczynie sporządzanym do wypieku chleba. Roślinne praktyki jedzeniowe, prezentowane w badanym dyskursie, zachowywały zatem ciągłość z dawną polską kulturą kulinarną i nawiązywały do wielu zapomnianych już dziśs znaczeń jedzenia.

Niezwykle ciekawym elementem analizowanego dyskursu były również wypowiedzi dotyczące wymiany doświadczeń związanych z przygotowywaniem roślinnych potraw na wzór tradycyjnych polskich dań mięsnych. Mięso z pewnością zaliczyć trzeba do pokarmów bardzo mocno zakorzenionych w rodzimych zwyczajach kulinarnych - najczęściej funkcjonowało jako pożywienie świąteczne i społecznie pożądane w okolicznościach niecodziennych i sytuacjach reprezentacyjnych, z czasem stając się jednak podstawą posiłków postrzeganych po prostu jako pełnowartościowe. Przeprowadzone w $2013 \mathrm{r}$. badania dotyczące aktualnych wzorów konsumpcji Polaków pokazały, że mięso to jeden z najważniejszych produktów w tzw. jedzeniu tradycyjnym, które oznacza praktyki żywienia kojarzone z domem i z tego względu traktowane jest bardzo emocjonalnie, jako łącznik z przeszłością i rodzinną wspólnotą ${ }^{25}$. Warto również przypomnieć, że produkty mięsne (głównie mięso czerwone) przez lata w polskim społeczeństwie uważane były za pokarm typowo męski, kojarzony z siłą i witalnością, dostarczający najwięcej kalorii, a przez to najbardziej odpowiedni dla fizycznie pracującego mężczyzny ${ }^{26}$. Dieta roślinna i jedzenie chudego mięsa zaś kojarzone było częściej z nawykami żywieniowymi kobiet. Niewątpliwie jednak w ostatnim czasie wzorzec konsumpcyjny, w którym mięso traktowane było jako produkt wysoko ceniony społecznie i najbardziej pożądany w ważnych sytuacjach obrzędowych i świątecznych ulega stopniowemu przekształcaniu. W diecie roślinnej zacierają się też kulinarne skojarzenia wiązane $\mathrm{z}$ różnicą płci, zanika znaczenie podziału

25 H. Domański, Z. Karpiński, D. Przybysz, J. Straczuk, Wzory jedzenia a struktura spoteczna, Warszawa 2015, s. I80.

26 Tamże, s. 221. 
na pokarm przeznaczony osobno dla mężczyzn i kobiet, a w jego miejsce pojawia się większe żywieniowe równouprawnienie.

Członkowie obserwowanych grup, zarówno mężczyźni, jak i kobiety, opisywali przejście na dietę całkowicie wykluczającą mięso jako dość trudne życiowe wyzwanie, szczególnie w kontekście ich wieloletnich wcześniejszych doświadczeń kulinarnych. $\mathrm{Na}$ forum grupy wymieniali się przepisami na warzywne zupy czy roślinne kotlety, które przywoływać miały utrwalone kulturowo skojarzenia z potrawami mięsnymi - ich smakiem, zapachem i wyglądem - doskonale znanym z kuchni domowych. Omawiając przyrządzane przez siebie roślinne potrawy, używali też czasami nazw tradycyjnych polskich dań z mięsa, takich jak rosół (warzywny), smalec (z fasoli), flaczki (z boczniaków) czy pasztet (z soczewicy). Przypomnieć tu można myśl Mary Douglas, która dostrzegła, że potrawy i kategorie posiłków zazwyczaj komponowane są według dobrze rozpoznanego kulturowego wzorca ${ }^{27}$. I tak, kategoria obiadu w polskiej kulturze kulinarnej od wielu już dekad zakładała obecność trzech podstawowych składników, czyli porcji mięsa (kotlet), surówki i dodatku w postaci ziemniaków, kaszy czy rodzaju mącznych (mączno-ziemniaczanych) klusek. W odwołaniu do tego wzorca członkowie obserwowanych grup wymieniali się przepisami na bezmięsne dania obiadowe, w których w miejsce tradycyjnego kotleta polecali sobie specjały roślinne, podawane na wzór znanych z wcześniejszych doświadczeń porcji mięsa - na przykład kalafiorowy kotlet smażony w panierce, kotlety z ciecierzycy, soczewicy lub soi czy też nuggetsy przyrządzane z grzybów.

W kategorię posiłku obiadowego w grupowych dyskusjach wpisywały się jednak nie tylko potrawy przygotowywane na wzór tradycyjnych dań mięsnych. Stosunkowo duża była także oferta „nowych” w kulturze polskiej propozycji kulinarnych. Powszechnie prezentowanym w postach daniem były na przykład porcje surowych lub gotowanych warzyw, łączone $\mathrm{z}$ wybranym rodzajem kasz (bulgur, kuskus, jęczmienna, gryczana) lub ryżu, makaron (czasem warzywny) z dodatkami w postaci pesto, szpinaku, sosu warzywnego lub serowego oraz dania jednogarnkowe - bezmięsne zupy, warzywne curry, risotto czy miska warzyw nazywana buddha bowl. Według nieco odświeżonego wzorca żywieniowego członkowie badanych grup komponowali też swoje śniadania i kolacje. Pośród potraw przyrządzanych najczęściej na posiłek poranny wymieniali owocowe owsianki, jaglanki, smoothie i koktajle przyrządzane często na bazie mleka kokosowego oraz

27 Por. M. Douglas, Odszyfrowywanie positku, [w:] M. Douglas, Ukryte znaczenia. Wybrane szkice antropologiczne, przeł. E. Klekot, Kęty 2007, s. 335-337. 
warzywne placki, sałatki lub kanapki. Na kolację zaś polecali sobie różne formy jarskich zapiekanek, tostów czy sałatek ze świeżych warzyw. Poza wykorzystaniem kulturowej wiedzy o gotowaniu uczestnicy internetowej komunikacji wymieniali się też swoimi doświadczeniami z zastosowaniem bardziej egzotycznych przypraw i produktów, dotąd rzadko spotykanych w kuchni polskiej, a wartościowych w komponowaniu dań bezmięsnych, takich jak tempeh i seitan, bataty, kim-chi czy okra.

Co ciekawe, w prowadzonych grupowych dyskusjach rzadko pojawiały się wskazówki dotyczące zakupu żywości u lokalnych producentów. Sporadycznie natrafić można było jedynie na posty reklamujące gospodarstwa produkujące żywność ekologiczną lub wypowiedzi zachwalające tanie zakupy świeżych warzyw na zlokalizowanych blisko domu rynkach czy targowiskach. Znacznie częściej rozmowy dotyczyły gotowych produktów niezawierających mięsa, które nabyć można było w popularnych sieciach handlowych. Użytkownicy grup wzajemnie polecali sobie artykuły spożywcze, które sami testowali i wykorzystywali we własnej kuchni - bezmięsne parówki, kotlety sojowe czy mielone w wersji wegetariańskiej. Stosunek wobec tego rodzaju pożywienia był jednak różny i raczej daleki od pełnej akceptacji. Autorzy internetowych wpisów często wnikliwie śledzili treść etykiet zamieszczonych na gotowych produktach i wspólnie dyskutowali o ich jakości, składzie oraz wartości odżywczej. Zwracali też uwagę na szkodliwe działanie produktów gotowych, obecność w nich sztucznych składników i konserwantów. Interesowała ich relacja ceny do jakości wybranego produktu oraz ogólna opinia o danym producencie żywności i stosowanych przez niego praktykach handlowych. Wyraźnie zauważyć można wciąż silne uwikłanie członków badanych grup w praktyki konsumpcyjne, koordynowane przez dużych producentów i sprzedawców żywności, którzy, diagnozując rynek, starają się odpowiadać na zapotrzebowanie odbiorców, także tych niejedzących mięsa.

Wszelkie zmiany zwyczajów żywieniowych pociągają za sobą zazwyczaj wzrost zainteresowania skutkami zdrowotnymi wprowadzanej diety. Dla uczestników badanego dyskursu internetowego jedzenie bazujące na produktach roślinnych także oznaczać miało przede wszystkim praktykowanie diety zdrowej i wartościowej dla organizmu. Wielokrotnie przywoływali oni w swych wypowiedziach przekonanie, że „spożywanie mięsa szkodzi zdrowiu i powoduje choroby", a dieta roślinna określana była jako „samo zdrowie”. Stosowanie tej diety stanowić miało działanie obronne przez chorobami wynikającymi z tzw. zachodniego stylu życia kojarzonego z pośpiechem i korzystaniem z najprostszych gotowych ofert, także w odniesieniu do jedzenia. Przy okazji zagrożenia epide- 
miologicznego na świecie użytkownicy obserwowanych grup używali też argumentu, że jednym ze sposobów zapobiegania rozwojowi choroby COVID-I9, poza stosowaniem się do ogólnych zaleceń sanitarnych, powinno być „przejście na dietę roślinną”, a w szczególności „unikanie konsumpcji surowego mięsa i mleka”. Mięso opisywane było jako „źródło chorób, pełne szkodliwych substancji i antybiotyków", a jego spożywanie kojarzono ze znikomym wpływem na odporność organizmu i powodowaniem zatruć pokarmowych. Dla użytkowników obserwowanych grup jedzenie cennych odżywczo produktów roślinnych nierozerwalnie wiązało się z wszechstronną dbałością o kondycję własnego ciała, aktywnym uprawianiem sportu oraz porzucaniem nałogów (na przykład palenia papierosów). Wspominali oni o spacerach (zazwyczaj ze zwierzętami), uprawianiu joggingu czy wykonywaniu ćwiczeń na macie (joga) oraz potrzebie odpowiedniej dawki snu i odpoczynku. Wymieniali się także zaleceniami dotyczącymi domowych, znanych z przekazów rodzinnych, sposobów na wzmacnianie odporności organizmu i zachowanie zdrowia.

Jak pokazaly badania, aktywne uczestnictwo w facebookowych grupach tematycznych, skupiających zwolenników diety roślinnej, przekładało się jednak nie tylko na wymianę i poznawanie kulinarnych receptur na określone dania, żywieniowych nawyków i przyzwyczajeń, ale także na przyjmowanie zaangażowanych postaw wobec zmian zachodzących w otaczającej rzeczywistości społecznej. Poglądy wyrażane w analizowanych przeze mnie wypowiedziach miały wyraźny związek z polityką ekologizmu. Przekaz informacji o jedzeniu dotyczył często praktyk w duchu zero waste i wykorzystywania w kuchni nie tylko zasadniczych składników spożywczych, ale także pozostających po nich roślinnych odpadów. Użytkownicy dzielili się swoimi sposobami na wykorzystanie warzywnych resztek i proponowali gotowanie z nich zup, potraw jednogarnkowych, przyrządzanie sałatek, chipsów lub pokarmu dla domowych zwierząt. Badani przeze mnie zwolennicy diety roślinnej starali się eliminować ze swoich codziennych nawyków używanie plastiku (mówili o rezygnacji z kupowania butelkowanej wody, niekorzystaniu z foliowych toreb), krytykowali konieczność nabywania w sieciach handlowych produktów spożywczych fabrycznie pakowanych w plastik. Działając w duchu ekologicznego myślenia, często sami podejmowali inicjatywy ogrodnicze i zajmowali się własną uprawą warzyw, w miarę możliwości hodowali rośliny w doniczkach, balkonowych skrzynkach lub planowali sezonowe uprawy w przydomowych ogródkach. Wysiewali nasiona i cierpliwie pielęgnowali rosnące plony, by móc na co dzień korzystać z nich we własnej kuchni. Praktyki jedzeniowe starali się traktować jako sposób na 
wdrażanie w swoje życie bardziej ekologicznych i pożytecznych dla środowiska rozwiązań, propagując znane z tradycji chłopskiej życie „w zgodzie z naturą". Dzielili się ze sobą również doświadczeniami dotyczącymi używania ekologicznych i nietestowanych na zwierzętach kosmetyków, pozbawionych substancji wywołujących alergię i produkowanych z naturalnych składników.

Często poruszanym w grupach tematem były też relacje ludzi ze zwierzętami, zazwyczaj domowymi, które wymagały opieki i troski ze strony człowieka, a jednocześnie zachwycały i rozczulały swoim wyglądem oraz zachowaniem. Wymianę informacji na ten temat inicjował najczęściej tekst zamieszczany w poście wraz ze zdjęciem lub filmem z wybranym zwierzęciem, który wyzwalał rozmaite komentarze pokazujące zachwyt i uwielbienie użytkowników grupy w stosunku do „żywych i wiodących szczęśliwe życie zwierząt", a także potrafiących wyrażać emocje i wykazujących zdolności empatyczne. Uczestnicy grupowych dyskusji czasami dzielili się z innymi prośbą o adopcję zwierzęcia (zwykle psa lub kota) przypadkowo znalezionego lub przebywającego w schronisku. Przede wszystkim jednak wyrażali oni swoje oburzenie wobec masowych hodowli, transportu i uboju zwierząt w celu pozyskania mięsa czy skór na futra. Bardzo często podkreślali brak jakiejkolwiek różnicy pomiędzy zwierzętami domowymi, które są pielęgnowane, rozpieszczane i kochane, a zwierzętami hodowanymi i zabijanymi w celu produkcji mięsa. Okrucieństwo wobec zwierząt oceniane było jednoznacznie jako działanie „niedopuszczalne i zasługujące na najwyższe kary” oraz jako „konsekwencja bezmyślnego rozwoju przemysłu żywieniowego na świecie". Powszechnie obecny dziś przemysłowy chów zwierząt opisywany był jako „zbrodniczy, sprzeczny z etyką $\mathrm{i}$ tradycją kulturową", przeciwstawny wobec znanej z kultury chłopskiej hodowli zagrodowej. Hodowlane działania przemysłowe nazywane były „największym okrucieństwem”, „porównywalnym jedynie z wydarzeniami z czasu I i II wojny światowej”, w tym z "hitlerowskimi obozami zagłady”, a jedzenie mięsa określano jako wspieranie „zbrodni czynionych na zwierzętach”. W opiniach członków badanych grup cenna była nie tylko rezygnacja z jedzenia mięsa, ale nawet czasowe ograniczenia w jego konsumpcji. Masowa hodowla zwierząt zaś oceniana była jako przeżytek odchodzącego świata kultury, krótkowzroczne działanie, w którym wyłącznie człowiek i jego potrzeby miały decydować o przyszłym losie planety.

Uczestnicy grupowych dyskusji, w ramach odrzucania okrucieństwa wobec zwierząt, ostro krytykowali także praktyki myśliwych oraz sprzyjające tym działaniom inicjatywy polityczne. Myśliwi i ich zwolennicy określani byli jako „mafia”, a podejmowane przez nich działania to „mord, 
masakra, arogancja, bezduszność i sadyzm”. Przedmiotem prowadzonych dyskusji była mocno utrwalona w nowoczesnym świecie opozycja człowiek - zwierzę, którą na wszelkie sposoby starano się kwestionować i podważać. W grupowych dyskusjach przywoływano m.in. oscarowe przemówienie Joaquina Phoenixa z 2020 r., a o jego wyjątkowości decydował nie talent czy dorobek aktorski mówcy, ale przede wszystkim zawarte w tym przemówieniu przesłanie dotyczące bezprawnego wykorzystywania zwierząt przez człowieka i bezpodstawne stawianie potrzeb ludzkich w centrum świata.

Członkowie obserwowanych społeczności konstruowali swoje wypowiedzi głównie w oparciu o wiedzę potoczną, opartą na przekazach medialnych oraz wynikającą z ich własnych codziennych nawyków kulinarnych. Dlatego też nie sposób odnaleźć w badanym dyskursie jakichkolwiek nawiązań do znanych z naukowych rozważań dyskusji dotyczących inteligencji roślin, ich statusu ontologicznego i moralnego, prezentujących skrajne etycznie podejście do spożywania istot roślinnych ${ }^{28}$. Nie wybrzmiewała również w badanym materiale kwestia związku jedzenia mięsa z męskością i patriarchatem oraz powiązania wegetarianizmu ze wzrostem społecznej dominacji kobiet ${ }^{29}$. W badanym środowisku wydawał się panować na tym polu względny egalitaryzm. Choć jednocześnie w obserwowanych sposobach wymiany myśli dostrzec można było pewne próby budowania opozycji wobec świata ludzi jedzących mięso, przede wszystkim jako tych, którzy są nieczuli na akty przemocy stosowanej w stosunku do zwierząt hodowlanych. Członkowie obserwowanych grup świadomi byli tego, że wybory dotyczące jedzenia mają duży wpływ na zmiany klimatyczne. Podkreślali, że podstawowym zagrożeniem dla planety i jednym z najbardziej widocznych skutków zmian klimatu jest obniżanie się poziomu wód gruntowych i nadmierne zużywanie zasobów wód głębinowych, co może w efekcie doprowadzić do braku wody pitnej. Porzucenie diety mięsnej postrzegali jako szansę na spowolnienie tego procesu, który pogłębia tylko produkcja mięsa pociągająca za sobą eksploatowanie i marnotrawienie ogromnych zasobów wody. Prowadzona na grupowym forum dyskusja stosunkowo rzadko dotyczyła polityki krajowej, krytykowano jedynie najważniejsze podejmowane w państwie antyekologiczne inicjatywy. Znacznie częściej w wypowiedziach pojawiały się nawiązania do ogólnoeuropejskiego czy też światowego dyskursu na temat ekologii i praw zwierząt.

28 Por. M. Marder, Is It Ethical to Eat Plants?, „Parallax” 2013, vol. 19, nr I, s. 29-37.

29 Por. A. Willetts, dz. cyt., s. II3. 


\section{Podsumowanie}

Reasumując, trzeba zauważyć, że prowadzenie badań etnograficznych online nie jest łatwym przedsięwzięciem, wymaga zmiany przyzwyczajeń badawczych, zaangażowania i ostrożności w wyciąganiu wniosków, które rzadko pozwalają dogłębnie zrozumieć motywy i sens działań użytkowników internetu ${ }^{30}$. Trzeba jednak podejmować tego rodzaju próby, by w ten sposób nabierać potrzebnego badawczego doświadczenia, ale również po to, by docierać do takich obszarów ludzkich aktywności, których nie sposób zgłębiać innymi, bardziej tradycyjnymi metodami. Tak szczegółowe dyskusje o codziennych praktykach kulinarnych, powiązane dodatkowo z odniesieniem do najbardziej aktualnych problemów współczesnego świata, nie toczą się obecnie w przestrzeni domowych kuchni. To portale społecznościowe służą dzisiaj w dużej mierze wyrażaniu najbardziej silnych emocji i dzieleniu się z innymi własnymi ocenami otaczającej rzeczywistości, stawianymi niemalże „na gorąco”. Antropolog musi zachować otwartość i wrażliwość wobec relacji społecznych nawiązywanych w komunikacji internetowej; musi docierać tam, gdzie toczy się życie współczesnych „tubylców”, gdzie omawiają oni ważne kwestie z własnej codzienności, do których należą zapewne działania kulinarne. Podejmowane w komunikacji internetowej praktyki dyskursywne ukazują jednocześnie uwikłanie nowoczesnego jedzenia w intensywne relacje społeczne, nie tylko w gronie najbliższych i doskonale znających się osób ${ }^{31}$.

Przeprowadzone badania potwierdzają, że w obecnym świecie wybory kulinarne, także w Polsce, coraz częściej są ściśle powiązane z problematyką etyczną, polityką i społecznym zaangażowaniem. Dieta roślinna stanowi zaś nie tylko sposób odżywiania oparty głównie na produktach roślinnych, ale przede wszystkim styl życia zakładający świadomą dbałość o własne zdrowie oraz określone nastawienie do świata, w tym wrażliwość na krzywdę zwierząt, troskę o zatrzymanie zmian klimatu i przyszły los naszej planety. Ekologizm wybrzmiewający w głosach obserwowanych zwolenników diety roślinnej postrzegać można także jako wytwór pewnego szczególnego momentu historycznego, w którym relacje pomiędzy społeczeństwem a środowiskiem wymagają wnikliwych przemyśleń oraz pełnych troski działań. Powrót do diety roślinnej, dostrzegalny obecnie również w społeczeństwie polskim, wpisuje się w określoną formę kultury, ukształtowaną w określonych warunkach społecznych i gospodarczych, a jednocześnie wydaje się

\footnotetext{
30 Por. K. Jurek, dz. cyt., s. 95.

3 Por. A. Caplan, dz. cyt., s. 5-6.
} 
sprzeciwem wobec rozwijanych w ostatnich latach globalnych praktyk konsumpcyjnych, zakładających dosyć nonszalancki sposób korzystania z wszelkich dóbr środowiska i natury, oparty między innymi na masowej produkcyjnej hodowli zwierząt. Mięso i jego konsumpcja jawi się tutaj jako reprezentacja starego porządku świata i myślenia egocentrycznego, a jedzenie roślinne stanowi zapowiedź nadchodzących zmian i wprowadzania proekologicznych praktyk także na poziomie życia codziennego, choć jednocześnie wyraźnie nawiązuje do zachowań znanych z dawnych praktyk żywieniowych. Warto w tym miejscu przypomnieć tylko, że mięso stanowiło znikomy procent diety nie tylko w tradycyjnej kulturze chłopskiej, ale także w plemiennych społecznościach zbieracko-łowieckich, w których, ze względu na trudności z upolowaniem zwierzyny, odżywiano się głównie zebranymi częściami roślin oraz drobnymi owadami czy skorupiakami ${ }^{32}$. Dostęp do mięsa zwiększył się wraz z udomowieniem zwierząt, ale jego jedzenie, jako znak dobrobytu i społecznego prestiżu, długo w kulturach rolniczych ograniczano tylko do sytuacji szczególnych ${ }^{33}$. W kulturze polskiej jeszcze w okresie przedwojennym kuchnia chłopska znana była w najszerszych warstwach społeczeństwa i opierała się przede wszystkim na produktach zbożowych - mąkach, kaszach i warzywach, głównie ziemniakach i kapuście. Początki zaś wprowadzania masowego spożycia mięsa w Polsce miały miejsce w okresie PRL-u i wynikały z polityki żywieniowej władz, zakładającej planowy wzrost produkcji zwierząt hodowlanych ${ }^{34}$. Poważne zmiany w sposobach konsumpcji mięsa, również w Polsce, wprowadził jednak dopiero globalny rozwój przemysłu mięsnego i rynków międzynarodowych, a konsekwencje tych procesów miały ogromny wpływ na degradację środowiska naturalnego, ale także upowszechnianie się etycznego podejścia do pozyskiwania żywności.

Użytkownicy badanych grup wykazywali w swoich dyskusjach dużą wrażliwość społeczną i zainteresowanie tym, co zdarza się w otaczającej ich rzeczywistości, a przestrzeń internetowego portalu stawała się doskonałą płaszczyzną ich wzajemnych interakcji i umożliwiała kontakty osób o podobnych zainteresowaniach i poglądach. Przy okazji wspólnych rozmów o jedzeniu członkowie grup starali się przekazywać sobie nawzajem komunikaty na temat nie tylko własnej codzienności, ale też najważniejszych wyzwań, przed jakimi staje współczesny świat. W ich ujęciu wybór diety ro-

32 J. Urbański, Spoteczeństwo bez mięsa. Socjologiczne i ekonomiczne uwarunkowania wegetarianizmu, Poznań 20I6, s. 40.

33 Tamże, s. I02-I05.

34 J. Straczuk, Smak trwania, smak zmiany. Preferencje i praktyki jedzeniowe Polaków w kontekście zmiany spotecznej, „Studia Socjologiczne” 2016, nr 3, s. 37. 
ślinnej był ważnym życiowym wyzwaniem, ale także oznaczać miał większą pokorę człowieka wobec zasobów planety i innych współżyjących na Ziemi istot, a przede wszystkim zwierząt. Dostrzec można jednak w przyjmowanej przez nich postawie pewien paradoks - obserwowani zwolennicy diety roślinnej byli przecież w dużej mierze zwolennikami egzystencji miejskiej i wciąż świadomie korzystali z rozlicznych udogodnień nowoczesnej cywilizacji czy ofert dużych producentów żywności. Wydaje się jednak, że byli oni dopiero w początkowym etapie swych starań o lepszą przyszłość, ale świadomi istniejących zagrożeń dla środowiska starali się wprowadzać zmiany w swoim życiu na miarę dostępnych im możliwości ${ }^{35}$. Odrzucenie produktów mięsnych, jako element przyjmowanego stylu życia, stanowiło manifestację ich społecznego położenia i wynikało z ich aktualnych życiowych dyspozycji, stanowiąc jednocześnie punkt wyjścia dla dalszych decyzji i działań możliwych do podjęcia w przyszłości ${ }^{36}$.

Warto również zauważyć, że poglądy wyrażane przez członków badanych grup są już od wielu dekad popularne wśród zwolenników dobrowolnego wegetarianizmu w krajach wysoko rozwiniętych (USA, Wielka Brytania, Niemcy, Holandia, Australia) ${ }^{37}$, a w Polsce pojawiają się dopiero w ostatnich latach. Wcześniej w polskiej tradycji kulturowej znany był raczej tradycyjny wegetarianizm mający swe źródła w odgórnie zaistniałej sytuacji społecznej, gospodarczej i politycznej, a jego najlepszym przykładem była dominacja roślinnego pożywienia w samowystarczalnej gospodarce chłopskiej ${ }^{38}$ czy też dieta jarska $\mathrm{z}$ konieczności stosowana w wielu polskich domach $\mathrm{w}$ okresie PRL-u. I choć przeprowadzone w $2013 \mathrm{r}$. badania dotyczące zwyczajów żywieniowych Polaków pokazały, że jedzenie mięsa jest wciąż popularne wśród zdecydowanej większości naszego społeczeństwaa ${ }^{39}$, to jednocześnie można zauważyć, że problematyka wykluczania lub ograniczania produktów mięsnych w praktykach kulinarnych pojawia się coraz częściej nie tylko jako temat podejmowany w debacie publicznej, ale także zyskujący na znaczeniu w codziennych i nieformalnych rozmowach o jedzeniu. Nie jest to już tylko kwestia elitarnej mody czy konsumpcyjnych kaprysów wyższych klas społecznych. Dostrzec można z pewnością stopniową intensyfikację poglądów, które zapowiadają koniec pewnej epoki, wywołany widmem

35 Por. N. Fiddes, Declining Meat: Past, Present... and Future Imperfect?, [w:] Food, Health..., s. 26r.

36 Por. uwagi na temat stylu życia: Styl życia. Koncepcje i propozycje, red. A. Siciński, Warszawa 1976.

37 Por. N. Fiddes, dz. cyt., s. 254.

38 Por. J.P. Dekowski, Przemiany tradycyjnego pożywienia wiejskiego na obszarze Polski środkowej, "Prace i Materiały Muzeum Archeologicznego i Etnograficznego. Seria Etnograficzna” 1979, nr 20, s. 171-218; B. Ogrodowska, Tradycje polskiego stotu, Warszawa 2012, s. I4-79, I02-151.

39 H. Domański, Z. Karpiński, D. Przybysz, J. Straczuk, dz. cyt., s. 62. 
globalnej katastrofy ekologicznej i wyczerpaniem się ideologii wiecznego rozwoju. A wyrażane w obserwowanych dyskusjach poglądy dotyczące wyboru diety roślinnej jako nowej praktyki żywieniowej są tylko dowodem tych zmian światopoglądowych powoli zachodzących także w polskim społeczeństwie, które z czasem znajdą zapewne swoje odbicie na poziomie ogólnych wartości kulturowych i będą miały wpływ na szersze działania gospodarcze w sektorze produkcji żywności i jej konsumpcji oraz decyzje polityczne dotyczące ochrony środowiska naturalnego.

\section{Bibliografia}

\section{Opracowania}

Caplan P., Approaches to the Study of Food, Health and Identity, [w:] Food, Health and Identity, red. P. Caplan, London-New York 2003.

Dekowski J.P., Przemiany tradycyjnego pożywienia wiejskiego na obszarze Polski środkowej, "Prace i Materiały Muzeum Archeologicznego i Etnograficznego. Seria Etnograficzna” 1979, nr 20.

Dijk van T.A., Badania nad dyskursem, [w:] Dyskurs jako struktura i proces, red. T.A. van Dijk, przeł. G. Grochowski, Warszawa 200 .

Domański H., Karpiński Z., Przybysz D., Straczuk J., Wzory jedzenia a struktura spoteczna, Warszawa 2015.

Douglas M., Odszyfrowywanie positku, [w:] M. Douglas, Ukryte znaczenia. Wybrane szkice antropologiczne, przel. E. Klekot, Kęty 2007.

Fiddes N., Declining Meat: Past, Present... and Future Imperfect?, [w:] Food, Health and Identity, red. P. Caplan, London-New York 2003.

Hammersley M., Atkinson P., Metody badań terenowych, przeł. S. Dymczyk, Poznań 2000.

Hine, Ch., Virtual Ethnography, Thousand Oaks 2000.

Jakubasek J., „Usta petne za jednym pociagnięciem” - internetowa kultura oralna, [w:] Antropologia praktyk kulinarnych. Szkice. Pongo, t. 5, red. R. Chymkowski, Warszawa 2012.

Jemielniak D., Życie wirtualne dzikich. Netnografia Wikipedii, największego projektu wspóttworzonego przez ludzi, Warszawa 2013.

Jurek K., Badania spoteczne w internecie. Wirtualna etnografia $w$ teorii i praktyce, „Nauka i Szkolnictwo Wyższe" 2013, nr I (4I).

Kowal E., „To, że ileś tam osób powiedziato, że nie może się wegetarianką nazywać, to nie znaczy, że rzeczywiście nie może" - tendencje w konstruowaniu i negocjowaniu tożsamości przez wegetarian i wegan, [w:] Kuchnia i stót w komunikacji spotecznej Tekst, dyskurs, kultura, red. W. Żarski, Wrocław 2017.

Kozinets R. V., Netnografia. Badania etnograficzne online, przeł. M. Brzozowska-Brywczyńska, Warszawa 2012.

Marder M., Is It Ethical to Eat Plants?, „Parallax” 2013, vol. 19, nr I.

Ogrodowska B., Tradycje polskiego stotu, Warszawa 2012.

Orszulak-Dudkowska K., Co kryja w sobie przepisy kulinarne? Od folklorystyki do antropologii zmystów, „Literatura Ludowa” 2010, nr 4-5.

Sade-Beck L., Internet ethnography. Online and Offline, „International Journal of Qualitative Methods" 2008, nr 3 (2). 
Straczuk J., Smak trwania, smak zmiany. Preferencje i praktyki jedzeniowe Polaków w kontekście zmiany spotecznej, „Studia Socjologiczne” 2016, nr 3.

Styl życia. Koncepcje i propozycje, pod red. A. Sicińskiego, Warszawa 1976.

Urbański J., Spoteczeństwo bez mięsa. Socjologiczne i ekonomiczne uwarunkowania wegetarianizmu, Poznań 2016.

Wejland A.P., Zatożenia teoretyczne i metodologiczne badań Internetu i w Internecie. Kilka uwag krytycznych, [w:] Homo interneticus: etnograficzne wędrówki w gtąb sieci, red. E. Jagiełło, P. Schmidt, Lublin 2010.

Willetts A., „Bacon Sandwiches Got the Better of Me”: Meat-eating and Vegetarianism in SouthEast London, [w:] Food, Health and Identity, red. P. Caplan, London-New York 2003.

Streszczenie: Przedmiotem rozważań podjętych w artykule jest dieta roślinna, której praktykowanie w kulturze współczesnej uwikłane jest silnie w projekty tożsamościowe i światopoglądowe oraz działania na rzecz zmian życia społecznego i kultury jedzenia. Autorka, wykorzystując metodę etnografii wirtualnej i analizę dyskursu, poddaje szczegółowej analizie dyskurs kulinarny, służący wzajemnej komunikacji zwolenników diety roślinnej w przestrzeni polskojęzycznego portalu społecznościowego (Facebook). Tego rodzaju analiza dyskursu służy pokazaniu specyfiki współczesnej diety roślinnej, ale także ukazaniu uwikłania interesujących autorkę praktyk kulinarnych w światopoglądowo zaangażowane działania proekologiczne, gospodarcze i polityczne. Dieta roślinna pojawia się zatem w przedstawionej analizie w szczegółowym kontekście społecznym i środowiskowym, zachowując swoją kulinarną specyfikę i autonomię, ale jednocześnie obrazując ważne procesy aktualnych przemian kulturowych w Polsce.

Słowa klucze: dieta roślinna, etnografia wirtualna, społeczności internetowe, dyskurs kulinarny, antropologia jedzenia

Summary: The subject of the considerations undertaken in the article is the plant-based diet, the practice of which in the contemporary culture is strongly entangled in identity and world-view projects and actions to change social life and food culture. The author, using the method of virtual ethnography and discourse analysis, examines in detail the culinary discourse used for mutual communication of the supporters of the plant-based diet in the space of a Polish social networking site (Facebook). Such an analysis of the discourse serves to show the specificity of the modern plant-based diet, but also to show the involvement of the author's interesting culinary practices in world-oriented pro-ecological, economic and political activities. Thus, the plant-based diet appears in the presented analysis in a detailed social and environmental context, preserving its culinary specificity and autonomy, but at the same time illustrating important processes of current cultural changes in Poland.

Keywords: plant-based diet, virtual ethnography, online communities, culinary discourse, anthropology of food 